\title{
The French Revolution in Germany and the Origins of Sociology
}

\author{
ERICR. LYBECK*
}

Francouzská revoluce v Německu a počátky sociologie

\begin{abstract}
The French Revolution was central to the emergence of modern society, and by extension, modern social science. However, not only French scientists contributed to the invention of sociology, nor for that matter did sciences necessarily begin by emulating natural science. Instead, this paper argues for a different origin of sociology from the professional faculty of Law. This trajectory emerged in early nineteenth century Germany, not in emulation of the French Revolution, but as part of a broader conservative reaction to French rationalism and imperial hypocrisy. Understanding these origins not only help us better understand the familiar sociology of Max Weber, or even Marx and Durkheim who were trained in this legal scientific tradition; this historical understanding reveals an important relationship between sociology and the State as well as conservative politics.
\end{abstract}

Keywords: Germany; Sociology; Law; Legal Science; Civil Service; Weber; Savigny

DOI: $10.14712 / 23363525.2018 .37$

\section{Introduction}

The French Revolution is undoubtedly a central event in the history of modern society, and, consequently, within sociology, the academic discipline occupied with studying modern societies. As Krause [2016] notes, the revolution remains one of many "privileged research objects" within the Western sociological canon, particularly within comparative-historical studies of radical social change [Skocpol 1979; Sewell 1985; Tilly 1968; Moore 1966]. Particularly in the wake of the Atlanticist historical tradition that emerged in the postwar era [Palmer 2014; Black 2001; Haller 2007], the revolution figures as the origin of several constitutional elements of modern society: popular elections; meritocracy and the removal of inherited privileges; nationalism; and rational, specialized administration.

The French Revolution is also important in sociology's self-conception insofar as sociologists believe sociology was founded as a "science of society" in France [Nisbet 1952]. ${ }^{1}$ In the image of the natural sciences, Auguste Comte claimed to have developed a means of controlling the further progress of society while avoiding the dangers and chaos of the revolution. As Gouldner [1970], Therborn [1976] and others have suggested, this

\footnotetext{
Dr. Eric Royal Lybeck, Department of Sociology, Philosophy and Anthropology, University of Exeter, EX4 4RJ Exeter, United Kingdom. E-mail: E.Lybeck@exeter.ac.uk

1 This applies in particular to sociologists in the English-speaking world, or those affected by the Atlanticist redrafting of history, which positioned Germany as having taken a "special path" to modernity [Blackbourn Eley 1984]. The same characterization of assumptions may not apply beyond the Anglophone world, as, indeed, the history of German law and German social science is well known and learned in Central Europe, Scandinavia and elsewhere.
} 
positivist vision articulated with the ameliorist agendas of bourgeois, welfare-state capitalism. Thus, sociology is believed to have been a) born in France, b) modeled on the natural sciences and c) reflective of a bourgeois, progressive ideology.

This paper will suggest that this origin story is only one piece of a more multi-linear story. While the French Revolution undoubtedly triggered the emergence of social science, the result was not necessarily progressive, nor particularly modeled on natural science. For it was within the German professional faculty of Law that the first recognizable science of society was developed in a context of the conservative reaction to the French Revolution.

\section{The French Revolution in Germany}

\section{German Hometowns and the Struggle for Jurisdiction}

Often non-Germanist scholars assume a rearview projection of what Imperial Germany had become by the end of the nineteenth century - chauvinist, statist, and powerful - and assume this character existed at the beginning of the century. In fact, in 1800, even Prussia could be described as a weak state with a strong bureaucratic military. In Mann's [2008] terminology, German states lacked "infrastructural power." Little connection existed between the aristocratic state bureaucracy and the people scattered across the German-speaking lands, including the considerable proportion living within the medium-sized "hometowns." Walker [1998] recovered the idiosyncrasy of these towns of no more than 10,000 denizens, which stood somewhere between the urban "Gesellschaft" and village "Gemeinschaft" later denoted by Tönnies [1988]. The majority of the German-speaking population in Central Europe lived in such medium-sized towns.

What the hometowns shared in common was their utter idiosyncrasy and variation, serving as "incubators" for a wide range of local customs, practices, and norms. Legal jurisdiction over them was vague, and constantly in flux. Indeed, jurisdiction was the central concern across the Holy Roman Empire. As Crosby notes, "the tradition of local jurisdiction had produced immeasurable legal variety in the secular laws of the Empire," consisting of overlapping canon law, common law, imperial ius commune and local regulations and procedures [Crosby 2008: 44]. The professional responsibility of jurists was mainly to know where to find the right jurisdictional authority and the rules through which, for example, Roman law was invoked over imperial law or vice versa.

For most of the first half of the second millennium, the application was haphazard and particularistic. During the sixteenth century, however, the lawyer's guilds began asserting the authority of jurists which contributed to an affirmation of Roman law, in particular, the usus modernus pandectarum ("modern application of the Roman pandects"), which they were taught in university. In the next century, inspired by the natural law philosophies of Johann von Justi and Christian Wolff, who abstractly deduced ideal systems of governance within a logic of "the possible," Enlightened despots in Germany envisaged their kingdoms as interlocking wholes, which could be organized as a body politic. This reorientation necessitated greater delegation to civil servants. At Halle and Frankfurt an der Oder (Viadrina), the first chairs of Kameralwissenschaft (administrative science) were established in 1727 [Lindenfeld 1997; Tribe 1988]. Cameralism amounted to Germany's contribution to the modernist shift Marc Raeff has called "the well-ordered police state": 
"What emerged into the open in the eighteenth [century] in most of Western and Central Europe is society's conscious desire to maximize all its resources and to use this new potential dynamically for the enlargement and improvement of its way of life" [Raeff 1975: 1222].

The results of Cameralist discourse traveled in two directions: first, an observable shift from "Recht" to "Gesetz," that is: questions of "Right" vs. "Law," capturing a distinction not present in the single English word: "Law." Gesetz, in contrast to sovereign Right, was the "lawyer's law" developed by trained jurists to reflect the holistic regulation of the national organism. This led to a second differentiation insofar as Gesetz came to refer to the "positive law" of a territory, distinguishable from the earlier conceptualization of Recht as derived from the principles of "natural law" (contract), or in earlier periods, "divine right." These important shifts toward lawyer's law and positive law prefigured the more substantial reformulation offered by the historical school after the Revolution but did not encounter actually-existing societies.

Rather, the new administrative science encouraged the production of legal "codes," such as the Allgemeines Landrecht für die Preußischen Staaten (1794) and the Allgemeines Bürgerliches Gesetzbuch (1811) enacted by personalist decree in Prussia and Austria respectively. Codes so derived were quickly deemed inadequate in the face of the diverse range of jurisdictions crisscrossing the Holy Roman Empire. Though a substantial start in the direction of modern jurisprudence, rarely did these decreed codes penetrate the local practices of townsmen in the Holy Roman Empire. This all changed with France's invasion of the Rhineland and the enforced enactment of the Napoleonic Code across the European continent beginning in 1804 with the Code civil des Français (1804), followed by the Code de Procédure civile (1806), Code de Commerce (1807), Code pénal (1810) and Code d'Instruction Criminelle (1811).

\section{The French Invasion}

By the flash of cannon fire, the diverse incubators of the idiosyncratic hometowns now held a single experience in common: imperial domination. Over the course of 10-20 years, burghers choked on the yoke of arbitrary French Rule across the geographic expression that would become a unified Germany. Without adequate military power of their own, unable to resist in the short term, the Germans waited and chafed under new institutions and foreign expectations. Their local reactions filtered up into a common national identity defined against the formalistic coded law of the "enlightened" Revolutionaries.

The earliest German territory to confront the French was the Left Bank of the Rhineland, invaded in 1792 following the battle of Valmy. Formal annexation would follow in 1795, under the geopolitical premise that France needed a territorial buffer between herself and her enemies. Though the French Revolution professed the ideals liberté, égalité, et fraternité, the military occupation produced a contradiction between these ideals and the practice of a military occupation. Lack of finances led to the order for militaries to live off the land, which led to enforced payments by levy and the requisition of food and livestock. Soldiers, especially officers who demanded luxuries in a time of scarcity, engaged in various abuses that could not be controlled remotely by the Paris authorities. Corruption and economic disruption led the region into deprivation. As Blanning notes, "during that 
terrible decade (1792-1801), monetary chaos, military expropriation, commercial disruption, and deindustrialization wiped out the considerable advances of the previous three or four decades" [Blanning 1983: 165-166].

While twentieth-century historiography highlighted the vigorous welcome the "German Jacobins" expressed upon hearing of the storming of the Bastille, as Blanning put it, "if a state as repellent as National Socialist Germany could find quislings to do its evil work, it is not surprising that revolutionary France should have attracted collaborators" [Blanning 1983: 13]. In fact, the overwhelming majority of Germans detested the French incursion, especially as religion became threatened. As the French expropriated Church lands, they directly interfered with religious doctrine. The clergy and laity soon began active resistance to the "godless" French. The German Jacobins realized their ideals diverged from French propaganda declaring participatory politics, egalitarianism, and collectivism when they were themselves ostracised and repressed by the French authorities. This reactionary fervor bled into a novel, emergent nationalism - a sense of being German in contradistinction to the French. People did not necessarily want a German state; they just did not want a French one.

French rule in the Rhineland soon led to the collapse of law and order. Criminals such as Schinderhannes, the "Slicer," and the goatriders (Bockreiter) preyed on Jews and others while squatting in the Left Bank woods, stealing much-needed firewood. These German Robin Hoods demonstrated to the French that the intruders were incapable of governing. The early atrocities and mismanagement under the protectorate cleared the way for toleration of a lesser evil when Napoleon ascended to the head of state, reinstating certain ancien regime values and estate categories. The acute struggle between the French, German Jacobins, and Rhenish counter-revolution in the 1790s was followed by an earnest attempt to integrate the Rhineland into the French Empire through a give-and-take process [Rowe 2003]. This led to a synthesis between the traditional layers of jurisdiction characteristic of the pre-Revolutionary period, with accommodation to the French on the matters that mattered most to the Empire: conscription and taxation.

Rather than attempt to "Frenchify" the Rhineland through language and education, Napoleon introduced festivals and heraldry valorizing "the Empire" rather than "France" and encourage a Bonaparte personality cult. By the end of the empire, the Rhineland had not only accommodated imperial institutions but learned to depend on them in their next struggle against the incursion of Prussia domination following the Congress of Vienna in 1814.

\section{German Nationalism}

Just as French officials sent by the early provisional government to the Rhineland were not taken seriously until they proved they were a power that was going to stick, the Prussians needed to demonstrate their durability and willingness to adapt to local environments. The structure of centralized bureaucracy inhibited this very interaction since the incoming official sent from Paris or Berlin was unfamiliar with local customs. The need to simplify regulations for administrative purposes - what Chancellor Hardenberg called "purification" - necessitated stripping the complex particularity of the alien territory into centrally recognized categories [Walker 1998: 200]. 
Yet, this was precisely what the hometown men sought to preserve, for they regulated and defended their jurisdictional sovereignty through this traditional, customary order. Just as they had always done within the Holy Roman Empire, burghers slowed the processes of change down to adapt to the new language and expectations of the incoming regime. In the Rhineland, ironically, this meant affirmation of the Napoleonic Code and French imperial institutions against the Prussians, for they had already survived twenty years of accommodation and negotiation to one "enlightened" despotism and were in no mood for a second course.

The French Revolution and the Napoleonic rule also greatly affected Germany beyond the Rhineland, especially following the rearrangement of territory which abolished the Holy Roman Empire and reduced member states from 360 to 36. Relative to the annexed Rhenish Left Bank, French exploitation throughout the Confederation was less direct but still substantial. There were three major aspects of French exactions: provisions, money, and men. Imperial demands forced many regions to industrialize under pressure, and German states had to update antiquated political structures through radical, top-down reform enacted by elites. Corporate privileges were attacked, and bureaucracies bulged, asserting state sovereignty within their borders through administrative centralization, division by departments, and hierarchical chains of command. Though always partial, these measures curbed local autonomy while undermining the foundations of the old order.

Following the humiliating defeat at Jena in 1806, Prussian generals were the first to reorganize themselves, even as the monarch, Frederick William III retreated to Königsberg and submitted to Napoleon's dictates. The young officer, Clausewitz, observed the French had channeled the nationalist fervor of an entire society into the war, producing not only the largest military fielded in Europe up to that time but better soldiers and a new cult of military personality [Black 2009]. To succeed in future conflicts, the German states must respond in kind, mustering the strength and passion of the Nation.

Clausewitz' superiors included the like-minded generals Gneisenau and Scharnhorst who recommended military strategies which recognized and defended the Volk as being distinct from the skittish monarch. The Prussian king soon conceded to the emerging nationalist spirit, recognizing the utility of the language of freedom and unity injected by France into Continental discourse. On the other hand, he personally sympathized with the forces of reaction emanating from Austria in the post-Napoleonic era. Under Metternich, Austria would restore the Old Regime monarchies and quell all traces of nationalist and radical political agitation. Prussia came to embody the new German spirit of nationalism, in part due to the greater efforts of civil servants to modernize the state, while channeling the emerging public consciousness. An axial tension would develop, which pitted notions of a smaller "Kleindeutsch" Germany containing Protestant Prussia and the so-called "third Germany," consisting of the states rolled over from the Confederation of the Rhine to the German Confederation, against the "Grossdeutsch" solution which would include the German-speaking parts of the multi-ethnic, majority Catholic Habsburg Empire.

The German national spirit emerged as a common response to the arbitrary rule of the French Empire in the ex-Holy Roman Empire, inspired by the resistance of local heroes, wilful generals and the Romantic Idealism of Herder, Hegel, Fichte, and their compatriots. But, only to the extent this vague Romantic vision was institutionalized within the Prussian state bureaucracy did the movement to position Germany as the leader of global 
civilization become manifest. As will be seen, the "bourgeois aristocratic" ethic of ministers Stein, Hardenberg, Humbolt, Gneisenau and their peers drew upon an earlier political philosophy scattered across Immanuel Kant's writings.

\section{The Birth of the Modern University}

\section{The Conflict of the Faculties}

Kant's political vision connected philosophical idealism to the interests of the modernizing state reformers. Levinger describes this as follows:

Kant was an advocate of the tutelary state: he believed that the government had a duty to educate its people for citizenship. He considered monarchy to be an imperfect form of government but one that would serve to represent the interests of the people until such time as the people had shed the shackles of irrationality and subservience [Levinger 2000: 35].

The German response to the rupture of the French Revolution was a reformist one, "top-down" only to the extent that the people were presently immature and unready to become autonomous. At the same time, to combat the French in the future, the nation must modernize and channel the productive strength of the nation, just as the cameralists recommended. The solution to this problem was education [Loader - Kettler 2002: 7-46].

Kant's "third way" between radical democratic revolution and monarchist reaction is rarely sufficiently understood by social scientists and historians, who attribute Germany's "special path" to modernity to a retrenched, backward estate-led "feudalization" [Blackbourn - Eley 1984; Steinmetz 1997]. However, to suggest the German people were preconditioned to arbitrary, centralized rule presupposes that a) centralized rule actually succeeded, and that b) the people and the state did not intentionally preserve medieval institutions because these were deemed more suited for social development.

In fact, the central institution rallied in support of the civil service reform "from above" was not the military or the industrial factory - though each had their parts to play. Rather, according to Kant's formula, the institution which would lead the German people and the human race toward perpetual peace and the pinnacle of civilization was the medieval guild par excellence: the university.

In the thirteenth century, medieval universities emerged out of guilds of students and teachers and were training centers for clergy, separated into three professional, or "higher" faculties of Theology, Law, and Medicine [Burke 2000: 82-99]. As the only literate society, the university-trained clergy became advisors to the leaders of the secular powers, and tutors to their children. By the eighteenth century, the medieval status differentiation of the three professional faculties remained, with Theology at the top, followed by Law, then Medicine. The philosophical faculty of liberal arts taught the lower trivium of grammar, logic, and rhetoric, and the higher quadrivium consisting of arithmetic (number), geometry (number in space), music (number in time) and astronomy (number in space and time) [Durkheim 2013]. Teaching in the liberal arts was of a lower order, and philosophers remained on the level with Masters of Music. On the one hand, this meant that philosophers indeed covered "all parts of human knowledge," as Kant would claim. However, unlike scholars in Law, Theology or Medicine, philosophers were not allowed the title of 
"Doctor." This meant that attempts to innovate in the realm of philosophy - moral, natural or political - were regularly censored by the Legal and Theological faculties.

Kant's "anthropological" texts were denied publication in this way, leading the philosopher to write Der Streit der Fakultäten (The Conflict of the Faculties), an appeal addressed directly to the monarch in the hopes of circumventing the censorship of the higher faculties [Kant 1992]. He argued that, unlike the "businessmen" (Geschäftsleute) of the higher faculties, philosophy was unconstrained by practical interests. Unbound by the directives of external power, philosophers were able to criticize the higher faculties according to the free judgment of "Reason." The university and state should recognize this value and give the philosophical faculty the autonomy to fulfill its critical mission:

The jurist, as an authority on the text, does not look to his reason for the laws that secure the Mine and Thine, but to the code of laws that has been publicly promulgated and sanctioned by the highest authority (if, as he should, he acts as a civil servant). To require him to prove the truth of these laws and their conformity with right, or to defend them against reason's objections, would be unfair. For these decrees first determine what is right, and the jurist must straightaway dismiss as nonsense the further question of whether the decrees themselves are right [Kant 1992: $40-42]$.

Philosophers could look beyond the law of the land as it is, to address what it could be in the future. The future holds the promise of cosmopolitan freedom - the end of the war - provided a reasoned constitution was constructed and ethically embodied in civic action [Kant 1784, 1939].

But, at present, we could only know that the law was being followed, not whether the law was infused with conscious moral spirit. Until we can be sure the people were properly educated, these constitutional reforms should be "from top to bottom" rather than "from bottom to top" [Kant 1992: 167]. Since the masses could hardly read at this stage, philosophy needn't address the "public" in its publications. Rather, the "free professors of law" in philosophy should resolve conflicts between the three higher faculties (by which Kant meant conflicts between Theology and Law, since his critique of Medicine involved only his eyeglass prescription). This did not imply freedom of speech for all, but rather a retrenchment of the authority of professors to interpret natural and social rights according to the principles of republican government, treating "the people according to the principles which are commensurate with the spirit of libertarian laws [...] although they would not be literally canvassed for their consent" [Kant 1992: 165].

The ascendance of the more "bourgeois" Prussian King Friedrich Wilhelm III in 1797 enabled the publication of Kant's tract, but it was not until the king sought counsel from his enlightened ministers, Stein and Hardenberg, that Kant's vision of philosophical autonomy was institutionalized at the University of Berlin in 1810, the first institution to award a Ph.D. in philosophy. The Stein and Hardenberg Reforms, as they are collectively known, responded to the pressures emanating from, or in reaction to Napoleon's Continental System. This necessitated flexibility in terms of both the natural law and theological justifications for the existing legal framework. According to Kant's planned outline for a new faculty consisting of "free professors of law," a counterweight to the entrenched authority of jurists could be drawn upon without disrupting the authority of education the ministers themselves drew upon to gain the king's confidence. In other words, the ascendance of the 
philosophical faculty to the rank of "doctor" should be understood, in context, as a demotion of the legal and theological faculties.

\section{Toward an Educated Civil Service}

Drawing on their cameralist pedigree, the aristocratic ministers encouraged legislation that would eliminate inefficient privileges and monopolies. These initial reforms were culminations of goals set during the absolutist period; however, their rapid unfurling in the context of the French imperial domination invoked a severe reaction of the traditional estates. Over time, however, nobles learned to translate their particularistic concerns into the emerging language of German nationalism - a discursive achievement which turned Prussian Junkers and their military into the bedrock of the German nation. Indeed, the military was the one realm of the civil service in which the traditional aristocracy preserved its autonomous authority. Their military academies contributed to the rapid remobilization and expansive armament and rationalization of the Prussian army in the coming century. As a sign of their independence, aristocratic military academies were the only educational institution training civil servants not contained within the new university.

It is striking that as guild privileges were dismantled across Germany, the medieval institution of the university retained its position, even as France established the specialized schools that became the grandes écoles. The French Revolution in Germany had dismantled and expropriated Church property, which removed the fiscal and authoritative basis for universities. So why did the State opt to revive, restore, and reform these decaying medieval husks?

Initially, German states could not afford to construct new institutions on the scale of the French écoles from scratch while paying reparations to Paris [Anderson 2004]. The convenient solution was a resuscitation of the dismantled and/or decadent universities, which had buildings, faculties, libraries, and so forth; and, being broke, the universities would welcome the resources the state offered in exchange for preservation of academic guild privileges and cash salaries. Salaries and legal titles made professors bureaucratic appointees of the State and replaced the hand-to-mouth household economies academics scraped from church property and their right to collect tutorial fees from students in their homes [Clark 2006].

But why recommit to the "unity of knowledge" and the medieval values of the academic guild? Ben-David suggests that scholars themselves recommitted to the "Humboldtian ideals" of student and academic freedom, stating: "occupational groups aspiring to professional status played no role in the movement" to reform universities [Ben-David 1977: 19]. This analysis only applies if one excludes the state civil service as a non-professional group. In fact, the bureaucrat, Stein, appointed the independently wealthy philologist, Humboldt, to the first directorship of the Ministerium der geistlichen, Unterrichts- und Medizinalangelegenheiten (Department of Spiritual, Education and Medicinal Affairs) in 1808. Humboldt never taught at the university, and his role was as administrator.

Beyond the civil service, precisely due to the rapid abolition of all other guild privileges, every German burgher was thrown into the same situation aristocrats had slowly adapted to during the previous century of bureaucratic reform [Hintze 1975; Rosenberg 1958]. That is, to preserve one's privileged position in society, one now had to demonstrate one's 
superior technical, moral and historical knowledge. The only route of access for burghers seeking status recognition was via the State, achievable either through military service or higher education. In this way, education became a marker of distinction in general, as, indeed, remained the case in Germany until well into the twentieth century [Münch 1992].

After the Freiheitskrieg, university graduates enjoyed special privileges, including deferral of military conscription from the infantry to the reserve (Landwehr) [Frevert 2004]. Professors became civil servants, and state bureaucracies began requiring passage of examinations, especially within Law, which necessitated increasingly advanced university education. Soon a discernible "Bildungsbürgertum" (educated bourgeoisie) became visible. As Kaschuba writes, "on the one hand, there was the narrower interest in educational and career qualification; but there was also a recognition of the special value of the 'culture of the educated' which functioned as a kind of bourgeois passe-partout, the absence of which could not be fully compensated for by either wealth or career qualifications" [Kocka Mitchell 1993: 410].

Indeed, the educated middle class was the ultimate goal of modernizing reformers in early nineteenth century Germany. Just as Gneisenau and Scharnhorst sought to capture the nationalist spirit of the people to maximize the power of the state, so did the Prussian civil service seek to channel and engender a spirit of nationalism within the public, especially the bureaucracy itself. As Nipperdey explains,

the Prussian reform movement was deeply influenced by philosophy; it was an idealistic and moralistic movement. This went beyond rhetoric, tone or superstructure, it also characterized its concrete goals $[\ldots]$ In the realm of political ideas and morality, reform centers on autonomy and responsibility; it seeks a neuer Mensch, a "reborn," a "refined" human being. This new man was not only the goal of the reforms; he was needed to carry them out. In this respect, it was much more than an institutional reform; it was, in the widest sense, an educational reform [Nipperdey 1998: 22].

In sum: the Kantian "third way" between revolution (France) and reaction (Old Regime) was political reform via education (Bildung).

The pinnacle of this modern system of education was the new University of Berlin: the fount of this neuer Mensch through which the German nation would become united in Geist, Kultur, and Bildung. Most historians agree that Stein and Hardenberg's "revolution from above" was at best "incomplete" or "stalled" after Waterloo and the immediate need for reform subsided. Yet, the University of Berlin remained an enduring legacy of the Kantian vision of advanced scholarship informing the modernizing civil service. As the first to offer the doctorate in philosophy, the university directed scholars toward basic research, dissertation writing, and the pursuit of "excellence." Many, though not all German universities, strove to replicate the Berlin model. In Prussia, Baden, Bavaria, Hanover, Hesse, Austria, and other Central European states, universities became admired institutions. The commitment of the Bildungsbürgertum likewise grew, creating a considerable market for academic publications, which further supplemented modern professors' stable incomes. Soon, Germany would lead the world in scientific and philosophical knowledge.

Undoubtedly the first conferral of the doctorate of philosophy at the University was an important, indeed, a pivotal step contributing to the emergence of the modern academic profession. However, Kant's struggle against the higher faculties was by no means settled with the stroke of a pen. Rather, the professional faculties continued to evolve in response 
to the new threat posed by philosophical knowledge and the epistemological turn. This reaction, however, was not rooted in the rationalist Enlightenment vision of Kant's original formulation; rather, all four faculties, including Philosophy, opted instead for the Romantic historicism of Herder, Hegel, Schelling, and Möser. The institutional structure remained, and doctorates of philosophy continued to be conferred. But, in practice, the progressive, Enlightenment vision of a tutelary state composed of enlightened civil ministers advising philosopher kings became sublimated into a conservative historicism: the reestablishment of authority within the new language of education, nationalism, and duty.

\section{The Institutionalization of Historical Legal Science}

\section{Historicism and Anti-codification}

Though only 24 years old in 1804, Friedrich Carl von Savigny had already secured his reputation with his 500-page volume, Das Recht des Besitzes (The Law of Possession), published the previous year [Savigny 1848]. A technical treatise on the differences between possession and property, in both Law and Fact, the text was an application of Savigny's developing a three-fold methodological approach to jurisprudence: as interpretation, history, and system. Savigny moved beyond the theoreticians of natural law, but equally transcended the practical juridical work of scholars who tracked down existing statutes in this or that Roman code to apply to a particular case and move on. In developing a mode of study which actually looked at original manuscripts and documents, while at the same time developing a consciousness of the entire period, Savigny was participating in a new, realistic legal science as recommended by the likes of Möser and Hugo [Mannheim 1986; Reimann 1989].

When Stein and Humboldt constructed the new University of Berlin in 1810, desiring the best researchers to steer the country into modernity, they called upon Savigny to lead the legal faculty. He agreed, provided training would cover Roman law and explicitly not the new Prussian legal code (ALR). The first cohort of chairs, which included Savigny in law, Niebuhr in history, Schleiermacher in theology, and Hufeland and Reil in medicine, would go on to become standard bearers in their respective disciplines. Each organized themselves around the new historicism [Ziolkowski 2004]. Though twentieth-century social theorists tend to credit Hegel with expressing the conservative spirit of 1810 [KingSzelenyi 2004; Marcuse 1941], this misrecognition results from the relative similarity of the historicist tradition developed by Savigny, Niebuhr, Schleiermacher, and others at the University of Berlin. The common origin was, in fact, Herder's conception of the Volksgeist [Iggers 1983; Lybeck 2015].

Importantly, since the legal faculty was responsible for the professional education of the civil service, Savigny's historicism was directly engendered in practice. The new German legal scientists came to distrust the abstract philosophy of natural law, which they saw embodied in the Hegelian school of philosophy - armchair philosophers, talking about history without performing the necessary labor of digging through archival manuscripts. Of the two Berlin academics, the jurist and the philosopher, Savigny offered a more radical methodological break with Enlightenment trends toward natural law, pointing instead to the necessity of historical research and particularistic, empirical observation. 
The novelty of Savigny's approach - paradoxically "modern" despite reaffirming the pedantic study of Roman antiquities - was that as he professed, in order to understand the usus modernus, the Roman Law as it is applied today, we must first understand the Roman law in its original context. Then, we must understand the centuries through which the Roman law has traveled and been adapted. Hence, his magnum opus is titled "The Roman Law in the Middle Ages." The Emperor Justinian and his jurists organized the Codex for particular purposes and codified existing practices at the time of writing, circa $530 \mathrm{CE}$. Meanwhile, in the course of the Law's development, these statutes have been adapted to newer needs of the Germanic peoples during the feudal, absolutist, and now, revolutionary periods. To adequately understand the significance of contemporary law, the jurist must understand its original basis as well as the particular, historical adaptations wherein those original bases no longer apply in whole.

A twofold spirit is indispensable to the jurist; the historical, to seize with readiness the peculiarities of every age and every form of law; and the systematic, to view every notion and every rule in lively connection and cooperation with the whole, that is, in the only true and natural relation [Savigny 1831: 64].

Savigny thus distinguishes two ontological entities: the "system" and the "Geist" of the people (Volk). A single true and natural relation exists organically between the two. The discursive effect, on the one hand, grounds the authority, back of the law, in the people and tradition.

In the earliest times to which authentic history extends, the law will be found to have already attained a fixed character, peculiar to the people, like their language, manners, and constitution. Nay, these phenomena have no separate existence [...] That which binds them into one whole is the common conviction of the people, the kindred consciousness of an inward necessity, excluding all notions of an accidental and arbitrary origin [Savigny 1831: 24].

However, there are many instances in which superficial understandings and the manifold nature of Law converted truth into error and vice versa, when "the error merely consists in the concrete being conceived too generally, or the really general too concretely" [Savigny 1867: xviii]. The role of the legal sciences was, therefore, to engender a professional analytic capacity within the student - especially judges, but also civil servants.

To train these jurists effectively, Savigny developed a stage model of successive Ages to explain the emergence of an autonomous legal system and thereby to encourage recognition of the role of jurisprudence in society. In its early, primitive forms, the law was the product of the customs of the people, working through "silently operating powers." As these become more complex, a stratum emerges to simplify the relationships between legal principles and case particulars, including sovereign rules. The law comes to exhibit two elements, one "political" - that is, the retained Geist of the people - and a second "technical" dimension emerges from the work of the educated jurists. In this more advanced stage, the law becomes that of experts trained in legal science.

The jurists now become more and more a distinct class of this kind; law perfects its language, takes a scientific direction, and, as formerly it existed in the consciousness of the community, it now devolves upon the jurists, who thus, in this department, represent the community. Law is 
henceforth more artificial and complex since it has a twofold life; first as part of the aggregate existence of the community [...], and secondly, as a distinct branch of knowledge in the hands of jurists [Savigny 1831: 29].

Recognizing the actual role of jurisprudence in the social process contributed to Savigny's criticism of hasty legal codification, both the French civil codes and the ones now proposed by Germans, most prominently Anton Friedrich Thibaut. Savigny's short pamphlet Vom Beruf unserer Zeit für Gesetzgebung and Rechtswissenschaft (On the Vocation of our Age for Legislation) was written in 1814 as a response to Thibaut's "philosophical school," which sought to identify a "law of reason" based on deductive logic. In contrast to the formalism of Thibaut's proposed new categorization, identification, and codification of positive law into a single logical system, Savigny insisted that not enough was known of the cultural "spirit" of the German people. Without precluding the possibility of codification in the future, the task of realistic historical jurisprudence managed by trained legal scientists was a necessary precondition for successful legislation.

Savigny distinguishes two potential sources of legal change: first, legislation and second, simplification of the complexity of existing custom. The new codes seek to impose by decree a holistic replacement, a gapless system constructed according to rational deduction, without reference to existing custom. He cites the hated Napoleonic Code, which annihilated a great part of the law from "a blind impulse against everything established, and with extravagant senseless expectations of an undefined future" [Savigny 1831: 71]. The code was neoclassically modeled on the ambition of the Roman code but filled in with new revolutionary principles. The code was not developed through legislation; rather the articles were largely consolidated out of the textbooks of a single jurist: Robert Joseph Pothier, whose contribution Savigny estimates to be at least three-fourths. This means the selection of subjects the code touched upon were those reflected in out-moded jurisprudential teaching, leading to substantial defects when the taken-for-granted detail of, for example, Roman property regulation was simplified and left without description - a "dead spiritless mode of treating the law" [Savigny 1831: 41]. Thus, perhaps the most important everyday legal needs, including property and marital law, were barely addressed by the new code, meaning most legal concerns were pushed onto the arbitrary discretion of judges. In other words, the procedure paradoxically produced the opposite of clarification, because it failed to adequately address the mechanisms and practices through which legal principles translate into judgments.

Savigny's critique of French codes echoed the emergent conservative critique of knowledgeable elites from a more elitist position. Problems in society and politics were not the inefficiency or unjustness of the status quo, but the meddling of know-it-alls without adequate experience to wield sovereignty. Burke, for example, chided the French National Assembly by noting the overwhelming membership of common lawyers, "the inferior, unlearned, mechanical, merely instrumental members of the profession."

It must evidently produce the consequences of supreme authority placed in the hands of men not taught to habitually respect themselves, who had no previous fortune in character at stake; who could not be expected to bear with moderation, or to conduct with discretion, a power which they themselves, more than any others, must be surprised [sic] to find in their hands [Burke 1982: 130]. 
Savigny extended this condescending observation to the whole of European civilization, Germany notwithstanding. Citing Bacon's recommendation that codes should not be undertaken unless a civilization's culture and knowledge surpasses that of the previous epoch, he noted that few ages meet these standards. Only during the "middle period" of a Nation's history - the summit of its civilization - should jurists try to pull off a code. Yet, this high watermark is precisely when no code is necessary. Even the great Roman code only became necessary during the fall of the Empire amidst corruption and intellectual death. Many inadequate codes were produced then, including the Edict of Theoderic, the Breviarium of Alaric, the Responsiones of Papiani (Lex Romana Burgundionum), and so on. The Justinian code was retained since it alone reflected the high standards of jurists trained in Roman legal science passed down since the Republic. Rooted in Republican freedom, the Justinian code retained the flexibility to allow a progressive element in organic unity with the permanent. This judicious spirit was embodied in the Codex, carrying it through many iterations and adaptations during the Middle Ages. Meanwhile, in the present era, French orators proclaim the Justinian Code obsolete and their own prefabricated expression to be perfect.

Thibaut, in Germany, now sought to do the same. Yet, "if we consider our actual condition, we find ourselves in the midst of an immense mass of juridical notions and theories which have descended, and been multiplied, from generation to generation. At present, we do not possess and master this matter but are controlled and mastered by it, whether we will see it or not" [Savigny 1831: 131]. The Germans could not begin a Code from scratch until the jurists cleared themselves of existing legal impressions. Even the suggestion that we could begin from scratch is absurd.

What, then, is to be done? In his appendix to the pamphlet, Savigny does not deny the possibility of legal codification many, many decades from now - perhaps, when Germany has fulfilled its promise as the new leader of Western civilization. For now, all scholars should do is prepare the way, ensuring that their knowledge of historical material and means of interpretation were sufficient. German jurists could generate a comprehensive manual (Handbuch), consisting of Positive Law, as well as History, Science, Literature, Theories, and Speculations. No individual jurist could be capable of producing this alone, so the project would require the cooperation of all "who have an inward call (Beruf) for the undertaking" [Savigny 1831: 184].

The significance of Savigny's vision was not limited to the legal faculties, however, if we recall the Kantian structure of the University of Berlin, where philosophers would contribute as "free professors of law," criticizing and updating the law in accordance with libertarian and cosmopolitan principles. Savigny, with one hand, denies this possibility and reasserts the authority of jurists. With the other, he extends the cooperative possibility of participation in a nation-building project - a Handbuch which will gather all the relevant material upon which the coming high point of civilization will rely. One can observe a delegation of a function, especially to the historical and philological faculties - with Niebuhr representing the former, and Buttmann, the grammarian, representing the latter at the University of Berlin. Meanwhile, as the Berlin university model was rapidly adopted across the German Confederation, novel disciplinary emergences in the fields of archaeology, Classics, and the earliest iterations of social science became visible in the work of the Germanist faction of the historical school Savigny called into being. 


\section{Germanists and Romanists}

Savigny's 1814 pamphlet demolished the codification project from the ground up; a project that would not resume for several decades. In the wake of his anti-codification triumph - which, like conservative agendas, in general, had the practical advantage of compelling subjects not to change - Savigny summoned the German historical school into existence. In 1815, with Karl Eichhorn and Johann Göschen, he founded the Zeitschrift für geschichtliche Rechtswissenschaft (ZGR), the journal which would become the institutional locus of the school. In addition to the founders, Jacob Grimm, Savigny's assistant, who had by then established his reputation as the leading scholar in German legal antiquarianism, was a frequent contributor.

Nearly as soon the journal was founded, a split developed between the so-called "Germanists" and "Romanists." The division reflected a dual partitioning; on the one hand, as a matter of technical need: one group of scholars dug deeper and deeper into the Roman history Niebuhr and his disciples uncovered year by year. Another group, represented by Grimm, Eichhorn and the Germanists, dedicated their attention to the particularities of the German "Gemeinwesen" (Commonwealth). The term referred to an ideal civil community, which supposedly actually existed at some point in the German past. Their task was to uncover the scattered, fragmentary evidence of what this traditional, medieval, ideal community consisted. Their results, incidentally, mirrored the constitution of the bygone hometowns, and the image of the Gemeinwesen emphasized a republican form of self-government consisting of equal bürgerliche citizens, contrasted against the absolutist centralized state.

The emphasis on municipal self-governance points to a second important distinction splitting the German historical school according to politics, which did not necessarily map directly onto the division of labor between Germanists and Romanists. In fact, each preferred "republican" to "imperial" topics, representing the latter in a negative light. The Germanist tradition focused on private law, and, in particular, a historical reformulation of property law according to the municipal constitutions of the Hanse cities, with the goal of maximizing the public freedom of citizens (and capital).

Yet, as Crosby [Crosby 2008: 116] notes, this commonwealth of equals was limited exclusively to property-holding men and excluded women who had previously participated and were legally recognized across many German lands. Similarly, outgroups, especially Jews, were deemed disqualified from suffrage and full legal rights due to their historic exclusion in the German Gemeinwesen, in spite of (or, more precisely, because of) the recent partial emancipation of Jewish citizens from 1812-1815.

The politicized dimension of the historical school incorporated a selective use of history to justify present interests. The Germanists' proto-racialized, anti-Semitism connected with the nationalist egalitarianism of Father Jahn and the Turnbewegung as well as the reaction of the hometown men to the liquidation of traditional rights. Though retaining the rhetoric of Hugo's "value-neutral" description of historical facts, the historical school justified their own contemporary political goals. By 1819, the political agenda of national liberalism was drawn squarely into the legal scholarship published in the ZGR due to a new wave of censorship. 
In the early days of the nineteenth century, nationalism was certainly not the ideology of conservative reactionaries; academics were heavily censored following the Carlsbad Decrees of 1819. The ascendant Romantic national liberalism, rooting freedom in history, rather than progress, struggled against the absolutist reactionaries led by Metternich and enforced by state police. Governments isolated the threat to order in the university, especially the nationalistic student societies.

Intensive censorship meant that the blooming national Republican political ideals of the revolutionary generation - which had ten years prior, been encouraged by the enlightened reforms seeking to modernize the state - now had to be smuggled into the arcana of Roman and German history [Ohles 1992]. Since censorship applied to works under a certain length, the voluminous texts produced by jurists often read as though they were intentionally boring; then, 250 pages or so in, the authors would begin radically charged assertions about the way Germany has always been "free" and will become so again. Only those aware of the internal conversation occurring within the legal, scientific disciplines realized the extent to which jurists were not only studying the law of the Roman Republic and speculating over the customary law of the German moot in the mists of the Black Forest; they were constructing a new constitutional framework.

Consider the Grimm Brothers' work on fairy tales: early on, the brothers turned from Savigny's study of Roman texts toward the more promising realm of Epics and Märchen (Fairy Tales). The Grimms invested themselves in the latent spirit of the people, which disclosed itself upon analytic elimination of cultural particularities. Only the artificial separation of the political boundaries across German-speaking states limited this recognition. For, the spirit is already present, the common folk have learned the same fundamental principles since the beginning of history from sagas, poetry and fairy tales. This common spirit provided the unity upon which a new legal order would be established.

Their project became increasingly philological, drawing on Herder and Humboldt's theories regarding the formative effect of language on human consciousness. Yet, the connection to Savigny's legal science remained. By examining the language and myth of the Volk, the Grimm brothers directly encountered the original source of the law. Understanding the morals of children's stories provided access to the morality of the people from which laws and customs emerged historically. For example, Grimm traced the legal concept of Lösegeld (compensation in tort claims) to the archaic form of the word "otter," thereby connecting to a story of a hunter who infringes upon the property rights of a farmer whose son had transformed into an otter [Crosby 2008: 112]. Similarly, the familiar Cinderella story of the glass slipper should be understood in terms of the custom of the groom fitting a shoe on his virgin bride as a symbol of property ownership exhibited before the community. In the context of anti-liberal censorship, Grimm and his legal, scientific colleagues sought enshrinement of these traditional customs in the rapidly rationalizing German legal apparatus, which they perceived as venal and arbitrary in contrast to the organic unity of the common German national spirit.

However, by 1848, amongst educated radical youth, Savigny and the Romanist school were considered the pinnacle of conservative thought. These were the sycophantic civil servants justifying the non-development of Prussian state and the continued fragmentation of the German nation. This tension played itself out within the Germanist jurisprudential 
literature. Georg Beseler, for example, wrote in 1836, that Roman law was constructed by an empire without freedom, whereas German law stood for liberty and the common good.

Equal, individual, free Germans, as members of an association (Genossenschaft), a family, had built the system through the complete public nature of the assemblies and courts. [...] The people were the sole source of their laws, and judges and lay judges constituted living control of the justice system. The German law was the law of the people (Volksrecht) in the fullest sense of the word, applied through the natural organ of the public people's courts, whereas Roman law was derived from a monarchy in the hands of the Emperor and his jurists! [Crosby 2008: 122].

By the thirties, one can see the hated forces of reaction projected onto the Romans (and Catholics). By extension, this denunciation adhered to the Romanist school of Savigny and his disciplines. The "Emperor" became a stand-in for the Habsburg nexus of European reaction in Vienna; freedom came to be embodied in the Germanist jurists retaining the customary law.

At the same time, the philological theories and comparative linguistics of Grimm, Schlegel, Bopp, and others marked a historical distinction which set the course for nineteenth-century anthropology, political science, law, and literature. Prior to the early nineteenth century, scholars assumed that all human languages derived from the original human tongue: Hebrew. But archaeological, historical and philological discoveries led to the identification of two distinct grammatical structures: Semitic and Indo-Aryan. Soon, the linguistic identification of Sanskrit, Greek, Latin, Persian, Germanic and Celtic languages was connected to a geographic origin in modern day Iran. The first linguistic "law," called "Grimm's Law," noted a non-trivial change in consonants that distinguished proto-Germanic languages from Romance languages.

At this time, the connection led to an affirmation of Christianity via the Western European Church and an Orientalist externalization of Jewish, Arabic and non-Vedic Asians. However, by the end of the century, racial theorists ascribed "Semitic" influence to "Roman" Catholicism, resulting in a purified conception of German blood, language, religion, and Nation [Field 1981]. The identification of language with the law was essential to the racist nationalism that would reach fevered pitch during the coming Age of Empire. As Jurasinski notes:

The emergence of two new sciences in the nineteenth century - comparative philology and evolutionary biology - permitted the belief in immemorial custom to be articulated in ways that emphasized its supposed basis in historical and scientific fact. [...] more reliable and scientific than ever before, scholars interested in the development of the law no longer had to locate the origins of legal customs in the proverbial "time out of mind" or in the era of Brutus [Jurasinski 2006: 7-8].

Once scholars realized that an Indo-Aryan language had been spoken from India to Norway, they could not resist the notion that common law and institutions had spread throughout the same territories, while retaining its identity, like language. The insight grounded ostensibly in fact - amounted to a wholesale conversion in the conceptualization of the law as an institution rooted in language, and by extension, race.

The seeds of future German race nationalism were set within collaborative research into the historical origins of law. Savigny's example, seeking the underlying systemic 
structure underlying cultural particularities, rooted the true national Geist in history. The project mutated discursively under the duress of political censorship and was projected into the accumulating collections of historical, archaeological and linguistic facts. At the same time, as noted by Osterhammel [2009], states began producing archives themselves on a massive scale, which along with newspapers, statistics and other media contributed to new forms of "second-order observation." Data began to accumulate to justify coming unified Germany - particularly in its non-Austrian Kleindeutsch variant. Indeed, one need consider but one of Savigny's students, Otto von Bismarck, to recognize the direct ideological bearing legal scientific discourse engendered among the ruling classes. By the time the Iron Chancellor arrived, the state envisioned by the pan-Germanists was taking shape. The triumph was experienced as progress, but also as a return to the natural unity of a common Volk sharing a common spirit.

\section{Conclusion}

This paper has presented an alternative historical origin for modern social science which is neglected in contemporary self-understandings of sociology. Rather than viewing modern society and sociology as being rooted in the French Revolution, the history of the institutionalization of historical legal science suggests that a more precise point of origin occurred within the German reaction to the French Revolution. While space prohibits further exploration of the trajectories of this tradition once established and embodied in the Prussian civil service), we can nonetheless see a) the first systematic research into the actual culture, norms and laws of people began in Germany, not French salons; b) natural science was of little significance in establishing social science, as, indeed, academic social science was established first in the professional faculty of law; and c) early social science was not reflective of bourgeois ideology; but rather that of the conservative reaction to such hasty modernization.

This does not simply mean Savigny and the historical school represented a return to the Old Regime, as their sublimated conflict with imperial Austria reveals. Rather, Mannheim explained that Savigny's aristocratic origins must be taken into account to the extent his organization of legal science reflected a general aristocratic orientation of the time.

[This] can be more easily derived from the nobility's positionally determined opposition to absolutism than from their formal need for distinction. [...] the disguised particularistic, estate-oriented argument, a self-justification hiding behind the totality of the nation can be explained by reference to the situation of the nobility at that time and by its collective sociologically determined designs [Mannheim 1986: 169].

In other words, Savigny articulated a discourse which, once publicized, earned elective affinity with the leading conservative impulses of his time - in particular the estates reacting to rapid changes in legislation. Mannheim further noted that the organicist, historical perspective that came to the fore after 1814, was present prior to Savigny's arrival at the University of Berlin as the first professor of Law, in the work of Hugo, Möser, and many others.

The articulation of Savigny's ideas must, therefore, be understood in terms of the broader social changes taken place around him. Only following the initial opening up 
of liminal space during the French Revolution, the resented experience of codified law imposed from abroad, and the subsequent expulsion of the Empire during the wars of liberation; only then did Savigny's re-articulation of a jurisprudence grounded in history become a discursive practice through which a new, modern German state would gradually come into being.

\section{Bibliography}

Anderson, Robert D. [2004]. European Universities from the Enlightenment to 1914. Oxford: Oxford University Press.

Ben-David, Joseph [1977]. Centers of Learning: Britain, France, Germany, United States. McGraw-Hill.

Black, Jeremy [2009]. War in the Nineteenth Century: 1800-1914. Cambridge: Polity.

Black, Lawrence [2001]. “The Bitterest Enemies of Communism”: Labour Revisionists, Atlanticism and the Cold War. Contemporary British History 15 (3): 26-62.

Blackbourn, David - Geoff Eley [1984]. The Peculiarities of German History: Bourgeois Society and Politics in Nineteenth-Century Germany. Oxford: Oxford University Press.

Blanning, Timothy C. W. [1983]. The French Revolution in Germany: Occupation and Resistance in the Rhineland, 1792-1802. Oxford: Oxford University Press.

Burke, Edmund [1982]. Reflections on the Revolution in France. London: Penguin Classics.

Burke, Peter [2000]. A Social History of Knowledge: From Gutenberg to Diderot. Wiley.

Clark, William [2006]. Academic Charisma and the Origins of the Research University. Chicago: University of Chicago Press.

Crosby, Margaret Barber [2008]. The Making of a German Constitution: A Slow Revolution. Berg.

Durkheim, Emile [2013]. The Evolution of Educational Thought: Lectures on the Formation and Development of Secondary Education in France. Routledge.

Field, Geoffrey G. [1981]. Evangelist of Race: The Germanic Vision of Houston Stewart Chamberlain. New York: Columbia University Press.

Frevert, Ute [2004]. A Nation in Barracks: Modern Germany, Military Conscription and Civil Society. Oxford: Berg.

Gouldner, Alvin W. [1970]. The Coming Crisis of Western Sociology. New York: Basic Books.

Grimm, Jacob - Grimm, Wilhelm - von Savigny, Friedrich Karl [1953]. Briefe der Brüder Grimm an Savigny: aus dem Savigny-schen Nachlass. E. Schmidt.

Haller, Gret [2007]. The Limits of Atlanticism: Perceptions of State, Nation, and Religion in Europe and the United States. Berghahn Books.

Hintze, Otto [1975]. The Historical Essays of Otto Hintze. New York: Oxford University Press.

Iggers, Georg G. [1983]. The German Conception of History the National Tradition of Historical Thought from Herder to the Present. Middletown, Conn. - Scranton, Pa.: Wesleyan University Press - Distributed by Harper \& Row.

Jurasinski, Stefan [2006]. Ancient Privileges: Beowulf, Law and the Making of Germanic Antiquity. Morgantown: West Virginia University Press.

Kant, Immanuel [1784]. Idea for a Universal History from a Cosmopolitan Point of View. Accessed: <http:// www.marxists.org/reference/subject/ethics/kant/universal-history.htm>.

Kant, Immanuel [1939]. Perpetual Peace. New York: Columbia University Press.

Kant, Immanuel [1992]. The Conflict of the Faculties. Lincoln: University of Nebraska Press.

King, Lawrence Peter - Szelenyi, Ivan [2004]. Theories of a New Class - Intellectuals and Power. Minneapolis: University of Minnesota.

Kocka, Jurgen - Mitchell, J. Allan (eds.) [1993]. Bourgeois Society in 19th Century Europe. Berg Publishers.

Krause, Monika [2016]. "Western Hegemony" in the Social Sciences: Fields and Model Systems. The Sociological Review Monographs 64 (2): 194-211.

Levinger, Matthew Bernard [2000]. Enlightened Nationalism: The Transformation of Prussian Political Culture, 1806-1848. Oxford: Oxford University Press. 
Lindenfeld, David F. [1997]. The Practical Imagination: The German Sciences of State in the Nineteenth Century. Chicago: University Of Chicago Press.

Loader, Colin - Kettler, David [2002]. Karl Mannheim's Sociology As Political Education. New Brunswick, NJ: Transaction Publishers.

Lybeck, Eric Royal [2017]. Comparative-Historical Sociology as Professional Practice. Human Figurations $6(1)$.

Lybeck, Eric Royal [2015]. History of the Concept of "Geist/Spirit." International Encyclopedia of the Social and Behavioral Sciences.

Mann, Michael [2008]. Infrastructural Power Revisited. Studies in Comparative International Development 43 (3-4): 355-365.

Mannheim, Karl [1986]. Conservatism: A Contribution to the Sociology of Knowledge. New York: Routledge, Chapman \& Hall.

Marcuse, Herbert [1941]. Reason and Revolution; Hegel and the Rise of Social Theory. Oxford: Oxford University Press.

Moore, Barrington [1966]. Social Origins of Dictatorship and Democracy; Lord and Peasant in the Making of the Modern World. Boston: Beacon Press.

Münch, Richard [1992]. The Production and Reproduction of Inequality: A Theoretical Cultural Analysis. In. Münch, Richard - Smelser, Neil J. (eds.). Theory of Culture. Berkeley, CA: Univ. of Calif. Press.

Nipperdey, Thomas [1998]. Deutsche Geschichte 1800-1866: Bürgerwelt Und Starker Staat. München: Beck.

Nisbet, Robert [1952]. Conservatism and Sociology. American Journal of Sociology 58: 167-175.

Ohles, Frederik [1992]. Germany's Rude Awakening: Censorship in the Land of the Brothers Grimm. London: Kent State University Press.

Osterhammel, Jürgen [2009]. Die Verwandlung Der Welt: Eine Geschichte Des 19. Jahrhunderts. München: Beck.

Palmer, Robert R. [2014]. The Age of the Democratic Revolution: A Political History of Europe and America, 1760-1800. Princeton, NJ: Princeton University Press.

Raeff, Marc [1975]. The Well-Ordered Police State and the Development of Modernity in Seventeenth- and Eighteenth-Century Europe: An Attempt at a Comparative Approach. The American Historical Review 80 (5): 1221-1243.

Reimann, Mathias [1989]. Nineteenth Century German Legal Science. Boston College Law Review 31: 837.

Rosenberg, Hans [1958]. Bureaucracy, Aristocracy, and Autocracy; the Prussian Experience, 1660-1815. Cambridge: Harvard University Press.

Rowe, Michael [2003]. From Reich to State: The Rhineland in the Revolutionary Age, 1780-1830. Cambridge: Cambridge University Press.

Savigny, Friedrich Carl von [1831]. Of the Vocation of Our Age for Legislation and Jurisprudence. Tr. by A. Hayward.

Savigny, Friedrich Carl von [1848]. Von Savigny's Treatise on Possession: Or, the Jus Possessionis of the Civil Law. Hyperion Press.

Sewell, William H., Jr. [1985]. Ideologies and Social Revolutions: Reflections on the French Case. The Journal of Modern History 57 (1): 57-85.

Skocpol, Theda [1979]. States and Social Revolutions: A Comparative Analysis of France, Russia, and China. Cambridge: Cambridge University Press.

Steinmetz, George [1997]. German Exceptionalism and the Origins of Nazism: The Career of a Concept. In: Stalinism and Nazism: Dictatorships in Comparison. New York: Cambridge University Press, pp. 251-284.

Therborn, Göran [1976]. Science, Class, and Society: On the Formation of Sociology and Historical Materialism. London: NLB.

Tilly, Charles [1968]. The Vendée. Cambridge, MA: Harvard University Press.

Tönnies, Ferdinand [1988]. Community and Society. Transaction Publishers. New Brunswick - New Jersey: State University.

Tribe, Keith [1988]. Governing Economy: The Reformation of German Economic Discourse, 1750-1840. CUP Archive.

Walker, Mack [1998]. German Home Towns: Community, State, and General Estate, 1648-1871. Ithaca, NY: Cornell University Press. 
Ziolkowski, Theodore [2004]. Clio the Romantic Muse: Historicizing the Faculties in Germany. Ithaca, NY: Cornell University Press.

Eric R. Lybeck is a Leverhulme Early Career Fellow working in Sociology and Education at the University of Exeter. At Cambridge, his doctoral study covered the topic of German and American higher education since 1800 revealing new perspectives on the emergence of social science in the nineteenth century out of pre-existing legal scientific discourses and curricula. His postdoctoral research explores a similar era in Britain drawing on the historical sociology of Norbert Elias. This study of an "academization process" traces a changing concept of an 'academic self' which transforms as different groups are included and integrated (or excluded) from the idea of the modern university. 